\title{
MODEL OF CONTEXTUAL-BASED ACADEMIC WRITING LEARNING MODULE
}

\author{
Afif Rofii \\ Universitas Batanghari Jambi, Indonesia \\ Email: afif_rofii@yahoo.com \\ Fathiaty Murtadho \\ Department of Apllied Linguistics, Postgraduate of Universitas Negeri Jakarta, Indonesia \\ Email: fathiaty_Murtadho@unj.ac.id \\ Aceng Rahmat \\ Department of Apllied Linguistics, Postgraduate of Universitas Negeri Jakarta, Indonesia \\ Email: aceng.rahmat@unj.ac.id
}

\begin{abstract}
APA Citation: Rofii, A., Murtadho, F., \& Rahmat, A. (2018). Model of contextual-based academic writing learning module $(\mathrm{R} \& \mathrm{D}$ at faculty of teacher training and education universitas Batanghari Jambi). English Review: Journal of English Education, 6(2), 51-60. doi: 10.25134/erjee.v6i2.1242.
\end{abstract}

Received: 12-02-2018

Accepted: 26-04-2018

Published: 01-06-2018

Abstract: This research and development aims to develop a contextual-based learning module for academic writing course to develop the students' writing skill. It adopts Borg \& Gall's model modified from Jolly and Bolitho's model of development steps. The development steps include: assessing the teaching materials currently implemented, designing and developing the module, judging module feasibility by experts, and testing module effectiveness. It applies mixed method approach to describe textual data qualitatively and analyze numerical data using t-test. The data were obtained from need analysis through document analysis, interview, observation, survey, and experiment. The analysis found that the lecturers and students need appropriate, practical and effective teaching materials that meet their needs. Therefore, the module of writing teaching material is developed by integrating the seven components of contextual approach in various learning activities. Th epracticality test suggests that the module is very pratical. The feasibility test 82.27 in average confirming that the module is very feasible to develop. The effectiveness test found that it is very effective reflected in the posttest mean score of experimental class (78.10) that is significally different from the control class (69.80). The tests of practicality, feasibility, and effectiveness come into conclusion that the developed module can be implemented in the academic writing class. As suggesstion, the lecturers and researchers are recommended to develop comprehensively teaching materials aligning with the students' needs.

Keywords: model, contextual-based, academic writing, module, research and development

\section{INTRODUCTION}

University is required to make a scientific work, either produced by the lecturers or the students. This scientific work is developed through academic writing activities. Writing is a complex activity requiring extensive and comprehensive knowledge (Martens, 2010). As defined by Akhadiah, et al. (1996), academic writing skill in term of formal writing is a complex skill requiring some knowledge and skills. Here, the author is required to have various abilities at once related to what will be written and how to deliver it in a good and right written language (Ridwan, 2011). 
Gaith (2002) states academic writing is a type of formal and critical writing activity to be presented to the readers in an academic domain based on scientific knowledge as well as scientific ideas and arguments. Gillet (2010) defines academic writing as a form of writing intended for specific audience and purpose as well as a clear structure. The lecturers are required to be able to publish a research article in journals, as well, the students are required to complete assignment related to academic writing activities. In fact, the reality indicates that there are many students unable to write well. It can be found in their writing works as theses and papers. Akhadiah (2008) argued that many students are difficult to write a wellestablished writing. Such difficulties include various levels of written language use as word choices (diction), sentence structures, paragraph developments, writing developments and the grammar rules.

Based on the provisional observations and interviews conducted to the third-semester students at the Faculty of Teacher Training and Education of Batanghari University, Jambi, several findings were found. Firstly, the learning process of academic writing is guided by the RPS developed by the lecturer without applying a particular approach. Secondly, the learning material is explained too fast by the lecturer. Third, it is difficult for students to understand the subject matter as the limited time available. Fourth, the learning process is delivered through lecture method. Last, students are difficult to obtain learning sources, lecture materials and rely merely on handouts made by the lecturers. These issues make the students to have lack motivation to learn and to master the academic writing materials.

Based on the problems formerly described, it is necessary to develop a module draft of academic writing learning that fits the students' needs. Sagala (2011) explains that the lesson planning is a process of the development of systemic learning that is used specifically in theories of learning and teaching ensuring the quality of learning. Therefore, teaching planning must be in accordance with the concept of education and teaching incorporated in the curriculum (Sagala, 2011).

Nasution (1997, p. 205) states that a module is "a complete stand-alone unit and consists of a series of learning activities developed to help students achieve a number of objectives defined clearly and specifically". In the same sense, Depdiknas (2008, p. 13) defines module as "a book written with purposed to ease the students in learning independently with or without the teacher guidance." Moreover, Mulyasa (2006) states that there are several advantages to learn by modules, such as focusing on learners' individual ability as they have the ability to work alone and more responsible for their actions.

In developing the learning module, the lecturers need to pay attention to the instructional material preparation model to implement. One of the models that can be used is the contextual teaching-learning approach (CTL). Johnson (2002, p. 24) states "CTL is a holistic system consisting of interrelated parts that produce an effect that exceeds what any single part could achieve." Moreover, Johnson (2002, p. 24) said that "each of these distinct elements of the CTL system contributes to helping students make sense of schoolwork; they form a system that makes it possible for students to see meaning in, and retain, academic material."

According to Rusman (2012), CTL is a learning concept that helps teachers to relate materials taught to the real-world situations of students and encourages students to connect their knowledge and its application in a daily life. Moreover, Nurhadi (2004) argued that CTL is a unit of learning concepts, in which teachers present real-world situations into the classroom and encourage the students to make connections between their knowledge and its application in their lives either as family or societal members. The learning process takes place naturally in the form of students' work and experience activities, not just the transfer of knowledge from teacher to student. CTL is suitable to overcome the problem of teaching academic writing that has been described as the CTL system will guide the learners to 
ENGLISH REVIEW: Journal of English Education Volume 6, Issue 2, June 2018

apply the seven components of CTL, namely: constructivism, inquiry, questioning, learning community, modeling, reflection, and authentic assessment in learning.

Based on the above description, researchers are motivated to overcome the problems occurred in the teaching of academic writing in the Faculty of Teacher Training and Education, Universitas Batanghari Jambi, by developing learning modules on academic writing materials integrating seven components of the contextual approach. Therefore, this research and development of learning module of contextual-based academic writing at Teacher Training and Education Faculty of Universitas Batanghari Jambi is important to do.

\section{METHOD}

The final objective of this research is to invent a model of teaching materials in the form of a learning module of contextual-based academic writing that is feasible, practical and effective in writing skill course at the Faculty of Teacher Training and Education, Universitas Batanghari Jambi. It is developed based on the objective conditions in the field. This research applies qualitative and quantitative approach using research and development method. Product development is carried out according to the research and development steps called the $R$ \& D cycle (Borg \& Gall, 1983). This R\& $D$ plays main part in improving the quality of education because it connects the systematic evaluation program with the development program in education domain (Gall, Gall, \& Borg, 2007). According to Borg and Gall (1983, p. 772), research and development is "a process used to develop and validate educational products”. Further, Gay (1992) says that this method is not to evaluate the theory but to develop effective products to use in schools to meet the pre-defined of special needs, such as training materials, teaching materials, media, and management systems.

This R\&D follows the steps developed by Borg and Gall (1983). Yet, the concept of Borg and Gall development model in its implementation can be modified to meet the needs in the real situation (Gall, Gall, \& Borg,
p-ISSN 2301-7554, e-ISSN 2541-3643 https://journal.uniku.ac.id/index.php/ERJEE

2007). Therefore, to easily implement this procedure, the ten steps of the Borg and Gall cycle are classified into four stages of research, as follows: 1) preliminary research; 2) model development planning; 3) validation, evaluation, and revision of the model; and 4) model implementation. The first is a preliminary research stage. The preliminary research includes theoretical review, analysis of empirical study results, evaluation of learning process, document analysis, needs analysis of learning process, and analysis of teaching materials generally used by lecturers. The second is the module development stage. This stage includes the formulation of objectives and criteria of the module, drafting of modules, peer assessment, revision I, limited testing, and continued with revision II based on the analysis results of the limited testing. The third is validation, evaluation, and revision stage, that is the steps carried out to acquire module that suits the students' and lecturers' needs. At this stage, the module is judged by the experts. The revision III, large groups testing, and revision IV of the module to be developed into hypothetical model. The fourth is the model implementation stage. This stage is conducted to investigate the effectiveness of the developed model. The testing of learning model effectiveness is conducted through experimental method. This activity is followed by observation, interview and questionnaire distribution to students and lecturers. It is then followed by final revision of the developed learning module.

The analysis is performed using qualitative and quantitative approach. The qualitative approach is used to get an overview and description of the learning real conditions in the classroom, the needs of students and lecturers, and the model developed. The qualitative approach analyzes the conceptual study of academic writing materials in universities, curriculum, discussion result with colleague, and expert validation data. Quantitative approach is performed to examine the effectiveness of contextual-based academic writing learning module. The examination is conducted to compare the effectiveness of the developed learning module with the 
conventional one used by lecturers in their daily lectures. The data on the implementation of learning are acquired from two classes, namely control group and experimental group. The quantitative data is pretest and posttest scores of both classes. The data were then analyzed by using t-test.

\section{RESULTS AND DISCUSSION}

In this research, the need analysis of the module (contextual-based academic writing) to be developed is carried out following four engagements. Data on the students and lecturers needs in the academic writing learning were validated using need analysis. The analysis involves four major activities, namely: 1) document analysis, 2) surveys through questionnaires given to lecturers and students, 3 ) direct observation to the academic writing learning process in the classroom; and 4) interviews with lecturers and students.

The first activity is document analysis that involves: curriculum, RPS the lecturers use in learning as well as the teaching materials used in academic writing course. The course identity, code, credit, description, learning outcomes, scopes and course prerequisite are collected by analyzing the curriculum. The result discovers the following information; 1) The teaching materials of the writing skill course used in Batanghari University are delivered in a difficult language to understand by the students, 2) The material does not meet the topics covered in the current syllabus, 3) the materials provided only expose the theories without supported by the conceptual and facts, 4) the level of meterials complexity should be aligned with learners' cognitive, 5) The examples presented are not contextual (different from the student's daily life), 6) The materials delivered by the lecture also overlap each other, unorderly presented from simple to complex materials, 7) The delivery of the materials is not centered to the students, 8) Form and technique of evaluation provided in the materials does not suitable, and 9) The learning objectives defined in the RPS do not adhere to the curriculum developed by the Faculty of Teacher Training and Education Universitas Batanghari Jambi. These facts cause the low level of the students' academic writing skills.

The second is need analysis of the developed module conducted by using questionnaire. The questionnaire consists of three components namely the teaching materials, learning methods and evaluation components. The first component prominently needs the material in accordance with the topic, learning objectives and characteristics of students, students do not merely need materials of writing theories but they also need more exercises, examples, and other supporting information as well as materials that synchronize with the students'characteristics by applying a particular approach or method. The physical appearance of teaching materials should be attractively presented in a colorful and unique illustration and presentation in order to improve student's learning motivation. The form and technique of evaluation should also be made varied in accordance with the competencies to be measured.

The investigation of teaching methods found that; 1) the students request learning materials applying specific approaches, 2) the method used in each topic should be varied to evade monotonous and be student-centered to facilitate them to study actively and creatively, 3 ) the methods used should consider the level of mastery and the background of the students, 4) the methods should explore the students' skill, and 5) the method should fit the learning objectives to achieve.

Need analysis on evaluation component founnd that; 1) the type and form of evaluation should be varied based on the competence to be measured, 2) the evaluation should not be administered at the end but also during the learning process, 3 ) the result of evaluation should be given back to the students so that they know their mistakes, and 4) if the lecturer evaluates using test, the scoring procedure should be provided in details.

Furthermore, the results of need analysis from the lecturers' view are also obtained through questionnaires based on seven components namely: rational, subject and content, gradation, methodology, design 
ENGLISH REVIEW: Journal of English Education Volume 6, Issue 2, June 2018

(layout), exercises, and other components. Rasionally, writing skill course requires the availability of learning materials where the content, language, appearance, and graph are reasonable. The materials should be practical: easy to use, keep, bring, and archive as well as be effective: have impacts on students.

Furthermore, it should provide a complete and varied learning materials involving the topics and learning outcomes to be achieved.

Besides, the materials should provide learning steps described in details; discussion on every topic provided with some examples and practice items; list of difficult vocabulary and their definition, as well as the detailed guide of learning materials. The lecturers also suggest to deliver the materials communicatively using familiar language the students easy to understand. The materials are presented gradually from the low level to the higher level. The basic and simple concept is presented first then proceed to the complex one. The illustrations provided meet the facts and concepts in daily life. The materials should be presented using various methods to avoid monotonous and use varied illustrations to make the materials be clear. The delivery and discussion should be focused on process skill based on the learning objectves. For design, the lecturers suggest to design the cover and content uniquely and interestingly to motivate the students to study. The module size and content should be proportional. The colors and location are syncronous and consistent to make clear the function. Font combination should be minimized. In addition, supplementary components such as reflection sheets, student worksheets, and answer keys are also required.

In addition to questionnaires, need analysis is also done through interviews with students and lecturers. Based of the interview with the lecturers, the following facts are obtained: 1) the materials should be organized or developed with a specific approach or method, 2) the materials should be organized according to the curriculum applied, 3) the materials should provide complete materials, and 4) the learning materials should accomodate the different characteristics of the
p-ISSN 2301-7554, e-ISSN 2541-3643

https://journal.uniku.ac.id/index.php/ERJEE

students. The interview with the students reveals that they need interesting, readable, understandable, feasible, practical, and effective learning material of academic writing organized with applying a specific approach or method.

Therefore, the data obtained from need analysis confirm that the development of materials model that adheres the students' and lecturers' needs should be carried out, that is a module of contextual-based academic writing learning that is feasible, practical, effective, attractive, contextual, and in accordance with the characteristics of students. It is aimed at improving the students' motivation, activity and competence on academic writing skills.

\section{The module design of contextual-based academic writing learning}

Based on observation, survey, interview, and document analysis results, the writer formulates a contextual-based academic writing learning module in the form of initial draft. The concept of the initial draft 1 was developed based on: 1) the principles of developing the teaching material model; 2) result of need analysis on student and lecturer obtained from questionnaire, interview and observation; and 3) document analysis results including curriculum, RPS and academic writing materials used in the learning process. The results of the analysis become the basis for formulating the development design of contextual-based academic writing learning module which consists of learning outcome, the main activities to be done, the material description, the summary, and the exercise components.

Learning outcomes are put at the beginning of each material to be learned which involve the competencies students should achieve in each learning material. The outcomes consist of attitude, knowledge, general skill and special skill as well. They are presented in active sentences using measurable operational verbs.

The main activities are the students learn the materials provided in the module. These activities required the students to follow the contextual approach procedure in the 
developed module. These are presented at the beginning before proceeding to the material description section.

The description contains the materials in one particular topic to be learned. It is presented in the module through learning activities that are divided into three, namely preliminary activities, main activities, and closing activities. After learning the activities presented in this module, students are expected to master the learning outcomes that are set on each material. The contextual approach component is integrated into the learning steps of the material presented.

The summary contains abstracts of the materials that have been completed. It is presented at the end of each topic in the module. This summary will ease the students to recall the materials they have learned.

Exercise/evaluation is conducted to know the achievement of the learning process, in addition to know the ability of students in understanding the materials they learned. As this academic writing learning module is contextually based, therefore, the evaluation is carried out during and at the end of the learning process of each topic as well as summative evaluation at the end of the module.

The developed model of draft $I$ is then tested in a small group of 9 third-semester students and the results are as follows: 1) in general the model of teaching materials is good; 2) the examples given are less varied; 3 ) the introductory language used is easy to understand; 4) the time to do the exercises should be added; 5) the exercises should be provided with clear instructions; and 6) the module should be equipped by a list of difficult words and their explanations.

A revision based on the student input on a limited trial is made. Afterwards, the validation or expert judgment test is performed. The results are as follows: 1) each subject is organized based on time allocated; 2) the materials are arranged orderly; 3 ) the direction in every exercise should be clearly written; 4) it is suggested to use appropriate illustrations with the topics; 5) consistency on writing patterns; and 6) vocabularies should vary and it is better to use a vocabulary close to the student daily life. Several expert inputs are then used as a guidance to revise the learning module to get the desired module. The developed module will then be tested for its effectiveness.

\section{The practicalities of contextual-based academic writing learning module}

The test of practicality is aimed at identifying whether the developed module is practical or not. Moreover, Yusuf (2005) stated that an instrument is practical if it is simple and affordable. There are some reasons to strengthen this statement; they are (1) it costs inexepensive; (2) it is easy to share which means the user of the instrument can apply and understand them it easily, the form and the language is not difficult to understand; (3) it is easy to grade; (4) it is easy to interprete; and (5) it does not waste much time.

The practicality of the model is being investigated in order to get the perception whether this model can be applied in individual learning or not. The practice refers to the acquiring or usability. There are some reasons that should be considered as a practical instrument. They are (1) the instrument must be easy to organize, save, or use; (2) the timing process of the administration must be short and brief; (3) it must be easy to interpret by experts or the teachers who lack of experience in instrument evaluation.; and (4) the good instrument must have a certain characteristic such as in expensive and to get for those who would like to use it as a guidance.

The practicality of the module can be tested in two ways, by observation and survey. The observation can be applied by using direct learning. This observation is implemented by giving observation sheets. The second way of taking the surveys is giving simple questionnaire. It is given to the lecturers and students. The questionnaire consists of students and lecturers assessment related to the practicality of the developed module. 
ENGLISH REVIEW: Journal of English Education Volume 6, Issue 2, June 2018

\section{Feasibility of contextual-based academic writing learning module}

After trial and revision in a small group, the examination of the module feasibility is then carried out. It is done by means of expert judgment using a questionnaire of module feasibility. In addition, expert judgments and inputs are also obtained through consultation and discussion. Based on input from the experts, the feasibility level of the developed model is obtained.

\section{Effectiveness of contextual-based academic writing learning module}

The effectiveness test of the module is done in Class III A1 and III A2 using an experimental
p-ISSN 2301-7554, e-ISSN 2541-3643

https://journal.uniku.ac.id/index.php/ERJEE method. This test is proposed to ascertain the impact of the developed module implementing in the classroom. Class III A1 is taught with teaching materials taken from the developed module, while class III A2 is taught using the conventional materials available. After the learning process completed, the test is administered to both classes. Further, the test results of both classes are compared and analyzed using t-test.

Based on the post-test result of both classes, the mean score of the experimental class is 78.10 and the control class is 69.80 . Further, the mean equality test is proceeded by means of t-test and the result is shown in the following table.

Tabel 1. Test result of mean variance

\begin{tabular}{l|llllll}
\hline \multicolumn{9}{c}{ Independent Samples Test } \\
\hline \multicolumn{2}{c}{} & \multicolumn{2}{l}{$\begin{array}{l}\text { Levene's Test for Equality } \\
\text { of Variances }\end{array}$} & & \multicolumn{2}{c}{ t-test for Equality of Means } \\
\cline { 3 - 8 } \multicolumn{2}{c}{} & F & Sig. & t & df & Sig. (2-tailed) \\
\hline \multirow{2}{*}{$\mathrm{Y}$} & Equal Variances assumed & .013 & .909 & 4.596 & 34 & .000 \\
\cline { 2 - 7 } & Equal Variances not Assumed & & & 4.596 & 33.970 & .000 \\
\hline
\end{tabular}

The table shows that the value of $t$-count equals to 4.595. Comparing to the value of $\mathrm{t}-$ table at the level of significance $\alpha=0.05$ and $\mathrm{df}=34$, the $\mathrm{t}$-count (4.596) is higher than $\mathrm{t}$ table (2.021). In conclusion, there is a significant difference between the mean score of the students' learning outcomes using the developed teaching materials and the students using conventional one. The mean score of learning outcomes of the students using academic writing modules developed is higher than those using the conventional one. As result, the null hypothesis (Ho) is rejected and the alternative hypothesis $\left(\mathrm{H}_{1}\right)$ is accepted.

It can be inferred, based on the test results, that the developed learning module has a high level of effectiveness. Therefore, the contextual-based academic writing modules developed are practical, feasible and effective to use in introductory writing skill lectures.

A questionnaire consisting of 79 items is administered to know the students' and lecturers' perception on the module feasibility. It is organized using Likert scale with five alternative categories: strongly agree (SS), agree (S), slightly disagree (KS), disagree (TS) and strongly disagree (STS). This test covers 21 aspects: 1) theme choice; 2) the accuracy of facts and concepts; 3 ) accuracy of illustration; 4) conformity with the development of science; 5) updated features of instances and references; 6) contextual; 7) alignment with the level of learners' development; 8) conformity with the level of social and emotional development; 9) message comprehension; 10) grammar and spelling correctness; 11) the standardized terms and symbols; 12) the meaning coherence of the chapters, sub-chapters and paragraphs; 13) the cohesion of inter-chapter, sub-chapter, paragraph, and sentence; 14) student centered; 15) develop process skills; 16) paying attention to safety; 17) variation of presentation; 18) conceptual coherence; 19) consistency of systematics; 20) chapters synchronization; and 21) completeness of presentation.

The students' responses to the questions on the feasibility questionnaire described in 79 items are as follows: $67.09 \%$ of students 
argued that the developed learning module was excellent (strongly agree) and $32.91 \%$ of students claimed that the learning module developed is good (agree). Based on the result, it can be concluded that students' perceptions on the feasibility of learning modules developed are very well (strongly agree). Meanwhile, the lecturers' perceptions of the 79 items of the feasibility questionnaire are as follows: $97.46 \%$ or 77 items answered strongly agree (very good) and $2.53 \%$ or 2 items are answered agree or good. It designates that the lecturers' perception on the feasibility of learning module developed is very good.

The advantage of this developed module is it is developed based on the analysis of lecturers' and students' needs so as to produce teaching materials with the following characteristics: 1) developed in accordance with the curriculum employed in the Faculty of Teacher Training and Education, Universitas Batanghari Jambi; 2) developed for special purposes; 3 ) accommodate the needs of lecturers and students; 4) focused on material interrelationship with students' immediate environment; 5) developed according to the characteristics of the students; 6) the module is feasible, practical, and effective, and 7) developed using contextual approaches prioritizing the seven components of contextual approaches (constructivism, inquiry, modeling, community learning, questioning, reflection and authentic assessment). Therefore, it can motivate the students to actively learn in groups or independently.

\section{CONCLUSION}

The results of needs analysis show that both students and lecturers require teaching materials in the form of academic writing module that fits their needs based on contextual approach. As result, it is then developed the learning module adhered the theories on the material development, the principles of material development, and the principle of material assessment.

Following the effectiveness analysis, it is known that the developed contextual-based academic writing module can improve students' learning outcomes. It can be consulted to the results of the effectiveness testing of teaching materials used in the experimental class. The scores showed a significant difference between the post-test mean score of the students after learning using contextual-based module (78.10) and the posttest mean score of the students in the control group (69.80). Afterward, the analysis of two means shows that $t$-count value is higher than $t$-table. The finding confirms that the academic writing performance of the class learning by using contextual-based module is higher than the class learning by using conventional one. This means that the developed academic writing module is effectively used in the learning of writing a proposal at the Faculty of Teacher Training and Education, Batanghari University of Jambi. The feasibility test conducted by giving questionnaire to the lecturers and students results mean scores $82.27 \%$. Both lecturers and students suggest that the developed contextual-based academic writing module meets the feasibility criteria, categorized into very feasible. Therefore, it can be concluded that the developed contextbased academic writing module is feasible, practical and effective to implement.

\section{REFERENCE}

Akhadiah, S. (2008). Penulisan ilmiah. Jakarta: PPs Universitas Muhammadiyah.

Akhadiah, S., Arsjad, M. G., \& Ridwan, S. H. (1996). Pembinaan kemampuan menulis bahasa Indonesia. Jakarta: Erlangga.

Borg, W. R., \& Gall, M. D. (1983). Educational research: An introduction. New York: Longman Inc.

Depdiknas. (2008). Panduan pengembangan bahan ajar. Jakarta: Direktorat Jenderal Manajemen Pendidikan Dasar dan Menengah.

Gall, M. D., Gall, P. J., \& Borg, W. R. (2007). Educational research: An introduction. Boston: Pearson Education, Inc.

Gay, L. R. (1992). Educational research competencies for analysis and aplication. New Jersey: A Simon \& Scuster Company Engliwood Cliffs.

Ghaith, G. (2002). Writing. Retrieved November 5, 2016 from http://www.nadaisland.com/ghaithwriting.html.

Gillet, A. (2010). Using English for academic purpose: A guide for students in higher education. Retrieved 
ENGLISH REVIEW: Journal of English Education Volume 6, Issue 2, June 2018

November 5, 2016 from http://www.uefap.com/writing/writfram.htm.

Johnson, E. B. (2002). Contextual teaching and learning. California: Corwin Press, Inc.

Martens, N. L. (2010). Writing, processes and techniques. New York: Nova Science Publishers Inc.

Mulyasa, E. (2006). Kurikulum yang disempurnakan: pengembangan standar kompetensi dan kompetensi dasar. Bandung: PT Remaja Rosdakarya.

Nasution. (1997). Berbagai pendekatan dalam proses belajar dan mengajar. Jakarta: Bumi Aksara.
p-ISSN 2301-7554, e-ISSN 2541-3643

https://journal.uniku.ac.id/index.php/ERJEE

Nurhadi. (2004). Pembelajaran kontekstual (CTL) dan penerapannya dalam $K B K$. Malang: Universitas Negeri Malang.

Ridwan, S. H. (2011). Metodologi pembelajaran bahasa: Aplikasi dalam pengajaran morfologisintaksis. Yogyakarta: Kepel Press.

Rusman. (2012). Model-model pembelajaran. Jakarta: Grafindo Persada.

Sagala, S. (2011). Konsep dan makna pembelajaran. Bandung: Alfabeta.

Yusuf, A. M. (2005). Dasar-dasar dan teknik evaluasi pendidikan. Padang: Universitas Negeri Padang. 
Afif Rofii, Fathiaty Murtadho, \& Aceng Rahmat

Model of contextual-based academic writing learning module 